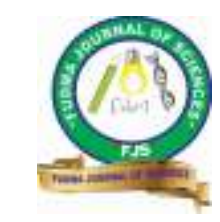

\title{
ASSESSMENT OF HEAVY METAL CONCENTRATION IN VEGETABLES DRIED ALONG FUNTUA-DANJA HIGHWAY KATSINA STATE, NIGERIA.
}

\author{
${ }^{* 1}$ Kankara, U. M., ${ }^{1}$ Rabiu Nasiru, ${ }^{1}$ Nuraddeen Nasiru Garba, ${ }^{2}$ Jamila Musa Kankara and ${ }^{3}$ Umar Musa Kankara \\ ${ }^{1}$ Physics Department, Ahmadu Bello University, Zaria \\ ${ }^{2}$ Department of Basic Studies Hassan Usman Katsina Polytechnic \\ ${ }^{3}$ Department of Biological Science Federal University Dutsin-Ma \\ *Corresponding authors email: umkankara90@gmail.com
}

\begin{abstract}
One of the major routes of heavy metal exposure to humans is via the consumption of vegetable. The study assessed the contribution of automobile emission on the concentration levels of heavy metals in some of commonly consumed vegetables in Katsina state, Nigeria using Atomic Absorption Spectrometry (AAS). Fresh and dried samples of five (5) commonly consumed vegetables were obtained from Danja-Funtua highway road, $0.5 \mathrm{~g}$ of each sample was measured into a clean dried beaker and $10 \mathrm{ml}$ of acidic mixture of $\mathrm{HNO} / \mathrm{HClO} 4 \mathrm{in}$ ratio 2:1 was added to the sample for digestion. The heavy metals concentration in this study ranges from $0.6-$ $75.5 \mathrm{mg} / \mathrm{kg}, 0.31-1.2 \mathrm{mg} / \mathrm{kg} 278-1470 \mathrm{mg} / \mathrm{kg}, 0.4-36.3 \mathrm{mg} / \mathrm{kg}$ and $28-65 \mathrm{mg} / \mathrm{kg}$ for Pb, Cd, Fe, $\mathrm{Ni}$ and $\mathrm{Cu}$ respectively. Levels of heavy metals were all found to be above the acceptable limits indicating that inhabitants are at risk of heavy metal contamination.
\end{abstract}

Keywords: heavy metals, vegetable, concentration level, AAS

\section{INTRODUCTION}

Vegetables and fruits are the most important components of human diet and it is well known that consumption of these food items on a regular basis is one of the possible health-improving practices (Sultana et al., 2017). The consumption of vegetable as food offers rapid and least means of providing adequate vitamins supplies, minerals and fibers(Asaduzzaman et al., 2015). Food is the major source of ingestion heavy metals in humans, particularly all categories of vegetables.One of the most essential aspects offood quality assurance is the assessment of heavy metal contamination ofthe food items (Rafi $\&$ GowdaT, 2017). Anthropogenic activities are a major source of heavy metal contamination which includes agricultural crop residue, emission from industries and vehicular emissions.Vegetables absorb metals from contaminated soils, besides from deposits on the parts of the vegetables exposed to polluted air (Haiyan and Stuanes, 2003). There has been a growing concern about food safety in recent years globally. Although many chemical elements are essential to metabolic functions of the human body, they can produce toxic effects when they are consumed in high concentrations, whereas some are toxic even at very low concentrations.

Open sun drying of vegetables and agricultural products has been widely practiced in the world for ages and is by far the most common means of preservation of farm produce. Though the drying technique is specific to the locality and also the commodity, the customary technique of open sun drying involves spreading the material to be dried on a thin layer on ground/mats or plastic sheet and exposing it to sun and wind (Latapi \& Barrett, 2006). The process of drying vegetables and other foodstuffs locally by open sun drying and especially along the roadside may lead to the contamination of the dried items by heavy metals or airborne radioactive elements.

The pollution of vegetables dried along roadside by heavy metals from automobile source is a serious worldwide environmental issue. These metals are released during different operations of the road transport such as combustion, component wear, fluid leakage and corrosion of metals. Lead, cadmium, copper and zinc are the major metal pollutants of the roadside environments and are released from burning of fuel, wearing out of tyres, leakage of oils, and corrosion of batteries and metallic parts such as radiators etc. (Akbar et al., 2006).

Heavy metals are deleterious due to their long biological halflives, non-biodegradable nature, and their ability to accumulate in different body parts (Arora et al., 2008).Therefore, consumption of vegetables contaminated with heavy metals may pose a risk to the health of humans. It is evident that prolonged consumption of foodstuff with unsafe concentrations of heavy metals may lead to chronic accumulation of heavy metals in the kidney and liver of human beings causing various disorders in numerous biochemical processes, leading to cardiovascular, bone, kidney and nervous diseases (Järup, 2003). This work is aimed at assessing the contribution of automobiles to the heavy metal concentration on vegetables dried along Funtua-Danja Highway. 


\section{MATERIALS AND METHODS}

The samples were collected and prepared using a method prescribed by Bello et al., 2016. Atomic Absorption Spectrometry was used for the determination of the heavy metal ( $\mathrm{Fe}, \mathrm{Cu}, \mathrm{Ni}, \mathrm{Cd}$ and $\mathrm{Pb}$ ) concentration.

\section{Sample collection}

Fresh and dried samples of five (5) commonly consumed vegetables were obtained from Danja-Funtua highway road. The study area was chosen because of the pronounced drying activity by the local farmers and the heavy traffic of the Highway. The details of the vegetable species, local names, scientific names and parts of vegetables used for analysis were all recorded. Thefreshsamples collected were dried under control condition so that no contamination is added to the samples as the result of drying. The dried samples were dried in sealed transparent polyethene nylon. The samples were tagged properly in polythene bags beforebeen taken to the laboratory for analyses.

Table 1: Sample specification

\begin{tabular}{|l|l|l|l|l|l|}
\hline S/N & Sample code & Common Name & English Name & Botanical Name & Part used \\
\hline 1 & TT & Tattasai & Bell Pepper & Capsicum annuum & Fruit \\
\hline 2 & KK & Kuka & Boabab leaves & Adansonia digitata & Leaf \\
\hline 3 & KB & Kubewa & Okra & $\begin{array}{l}\text { Abelmoschus } \\
\text { esculentus }\end{array}$ & Fruit \\
\hline 4 & ZB & Zobo & Roselle & Hibiscus sabdariffa & Fruit \\
\hline 5 & ZG & Zogale & Moringa & Moringa oleifera & Leaf \\
\hline
\end{tabular}

\section{Sample preparation}

$0.5 \mathrm{~g}$ of each sample was measured into a clean dried beaker (100ml), $10 \mathrm{ml}$ of acidic mixture of $\mathrm{HNO} / \mathrm{HClO} 4$ in ratio 2:1 was then added to the sample for digestion. The samples were evenly distributed in the acid by stirring with a glass rod; the beaker was then placed on the digestion block in a fume cupboard for 2 hours at temperature $150^{\circ} \mathrm{C}$ for digestion. The digested samples were kept at $4^{\circ} \mathrm{C}$ prior to analysis. A Buck scientific atomic absorption spectrophotometer was used for lead $(\mathrm{Pb})$, cadmium $(\mathrm{Cd})$, nickel $(\mathrm{Ni})$ and copper $(\mathrm{Cu})$ and Iron (Fe) analysis.

\section{Measurement of heavy metals}

The measurement of heavy metals was carried out using atomic absorption spectrophotometer with model (AA-6800 Shimadzu Japan) situated at Multi-purpose Laboratory A.B.U. Zaria. AAS works base on the principle of ionization of the atom. As atoms are made of electrons in their shells, if sufficient energy is gained by the atom an electron can be ejected from the atom. This ejection of electron from the atom is called ionization. This leads to the creation of a vacancy which is subsequently filled by another electron with the emission of a photon. Atoms of an element emit a characteristic spectral line. Every atom has its own distinct pattern of wavelengths at which it will absorb energy, due to the unique configuration of electrons in its outer shell. This enables the qualitative analysis of a sample. The concentration is calculated based on the Beer-Lambert law.
Absorbance is directly proportional to the concentration of the analyte absorbed for the existing set of conditions. The concentration is usually determined from a calibration curve, obtained using standards of known concentration.

Calibration curves were obtained by running different concentrations of standard solutions for each heavy metal using measured absorbance on the instrument. The results of the analysis were validated by digesting and analyzing standard reference materials (Lichens coded IAEA-336) following the same procedure.

\section{RESULT AND DISCUSSION}

Concentration of carcinogenic and non-carcinogenic heavy metals in vegetable samples

The average concentrations of carcinogenic and noncarcinogenic heavy metals in the investigated dried vegetable samples are presented in Figures4.1a and 4.1b. The concentration of the heavy metals was observed to vary significantly across the studied samples with Fe having the highest content with average concentration of $4371 \mathrm{mg} / \mathrm{kg}$ while the lowest metal content was for $\mathrm{Cd}$ with average concentration of $1.14 \mathrm{mg} / \mathrm{kg}$, respectively. The trend of the heavy metal contents according to average concentration found in the studied samples followed: $\mathrm{Fe}>\mathrm{Ni}>\mathrm{Pb}>\mathrm{Cu}>\mathrm{Cd}$. 
The concentration was also observed to have a wide distribution across the five studied vegetables. The variations observed may be as a result of the influence of uncontrolled anthrapogenic activities such as aerial deposition of heavy metals mainly by exhaust from vehicles leading to contamination of the vegetables in the studied area. Among the carcinogenic heavy metals studied in the present work, $\mathrm{Pb}$ has the highest concentration in all the samples. The concentration of lead ranges from $0.6-75.5 \mathrm{mg} / \mathrm{kg}$ and the average value was found to be $37.38 \mathrm{mg} / \mathrm{kg}$. Highest levels of $\mathrm{Pb}$ were recorded in TT followed by KB and the least values were recorded in KK. Lead pollution has been shown to be commensurate with population/vehicular density. One of the means through which lead contamination occur in vegetables is through air deposition. In this study, the concentrations of $\mathrm{Pb}$ are significantly higher than the permissible levels by FAO/WHO in vegetables of 0.3 $\mathrm{mg} / \mathrm{kg}$. The other carcinogenic heavy metal studied in this work is Cadmium. The permissible limit for $\mathrm{Cd}$ in vegetables is 0.2 $\mathrm{mg} / \mathrm{kg}$ as reported by FOA/WHO. The concentration of $\mathrm{Cd}$ exceeds this limit by an average value of $1.14 \mathrm{mg} / \mathrm{kg}$.Higher values have been previously reported for leafy vegetables cultivated along road sides $(0.27 \mathrm{mg} / \mathrm{kg})$ by (Oluwole et al., 2013).
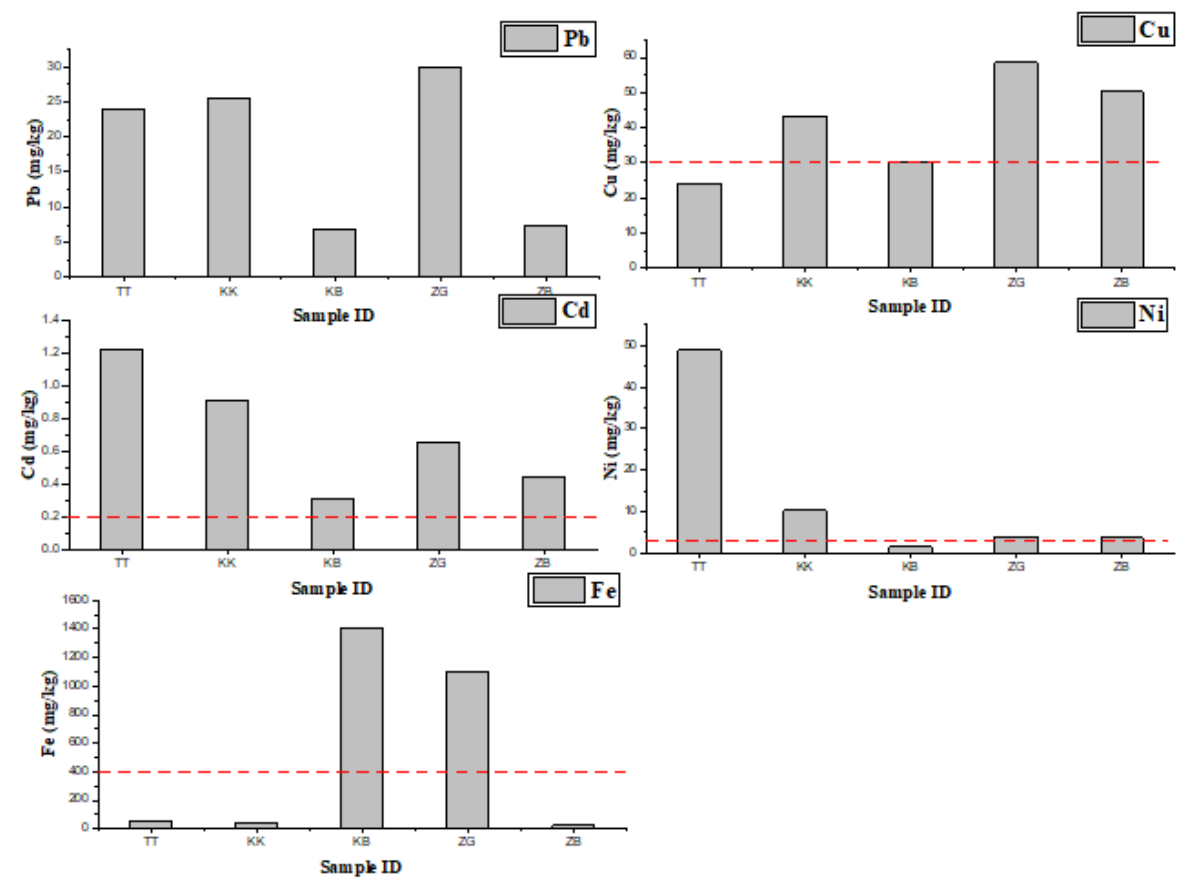

Fig. 1: Concentration of Heavy metals in the studied vegetable samples dried under controlled condition 

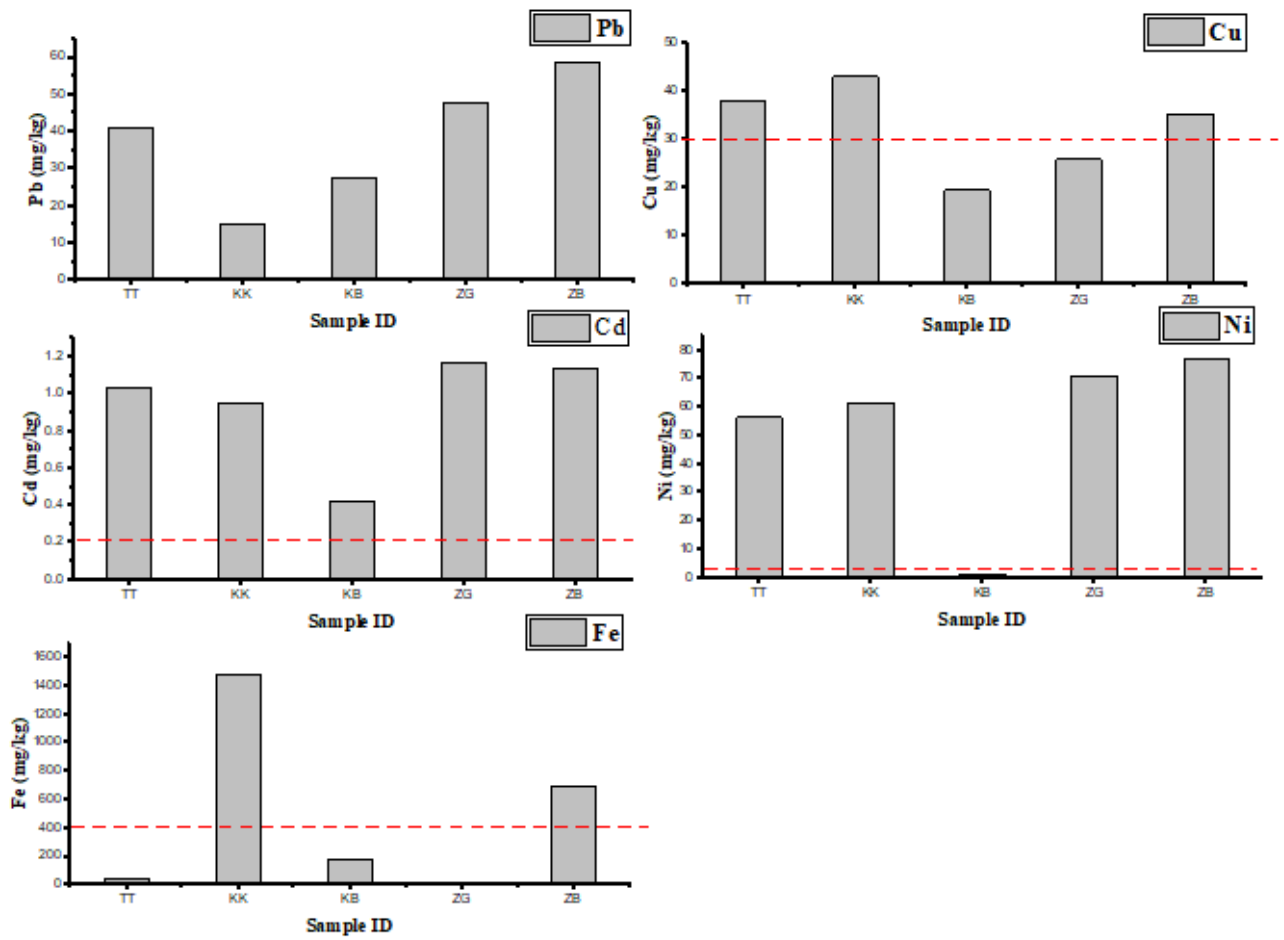

Fig. 2: Concentration of Heavy metals in the studied vegetable samples dried under normal drying condition

Average concentration of all non-carcinogenic heavy metals studied in the work was observed to be generally higher in leafy vegetables as compared with fruit vegetables. Fe was observed to be particularly higher in green vegetables $(\mathrm{KK}$ and $\mathrm{KB})$ than in fruits vegetable samples. The reason might be because Fe participates in chlorophyll synthesis and photosynthesis a process that characterizes green plants. However, it was reported that excess $\mathrm{Fe}$ in the body may be a contributing factor in etiology of heart disease and type 2 diabetes (Kashem \& Singh, 1999). Besides $\mathrm{Fe}, \mathrm{Cu}$ and $\mathrm{Ni}$ were also detected in all the samples with $\mathrm{Ni}$ having the least concentration. $\mathrm{Cu}$ is essential to human life as metalloproteins and function as enzymes, however, critical doses leads to health risks such as anemia, diabetes, inflammation, kidney and liver dysfunction and vitamin C deficiency (B. et al., 2012).

The safe limits of $30 \mathrm{mg} / \mathrm{kg}$ and $5 \mathrm{mg} / \mathrm{kg}$ in vegetables as recommended by FOA/WHO is significantly lower than the $43.3 \mathrm{mg} / \mathrm{kg}$ and $35.5 \mathrm{mg} / \mathrm{kg}$ average levels of $\mathrm{Cu}$ and $\mathrm{Ni}$ respectively.

\section{CONCLUSION}

This study assesses contribution of automobile emission on heavy metal contamination of vegetables dried along Funtua Danja highway in Katsina State, Nigeria. A wide variation of heavy metal concentration was observed across the studied samples with $\mathrm{Fe}$ and $\mathrm{Pb}$ having the highest content. These high concentrations of heavy metals (carcinogenic and noncarcinogenic) from the studied vegetable samples were found to be contributed mainly by the exhausts released by automobiles along the highway. All the concentrations were found to be above the recommended limits, this indicate that resident of the study area are at high risk of heavy metal pollution.The authorities responsible for environmental protection should try and address the problems of risen heavy metal contents, especially the carcinogenic heavy metals, in the environment.

\section{REFERENCES}

Akbar, K. F., Hale, W. H. G., \& Headley, A. D. (2006). Heavy Metal Contamination of Roadside Soils of Northern England. 2006(4), 158-163.

Arora, M., Kiran, B., Rani, S., Rani, A., Kaur, B., \& Mittal, N. (2008). Heavy metal accumulation in vegetables irrigated with water from different sources. Food Chemistry, 111(4), 811-815. https://doi.org/10.1016/j.foodchem.2008.04.049

Asaduzzaman, K., Khandaker, M. U., Amin, Y. M., Zainuddin, Z., Farook, M. S., \& Bradley, D. A. (2015). Measurement of radioactivity and heavy metal levels in edible vegetables and their impact on Kuala Selangor communities of Peninsular Malaysia. Radiation Protection Dosimetry, 167(1-3), 165-170. https://doi.org/10.1093/rpd/ncv237

B., L., Shivpuri, K., Tripathi, V., \& K. Dikshit, A. (2012). Assessment of Toxic Metals in Agricultural Produce. Food and 
Public Health, 2(1), 24-29.

https://doi.org/10.5923/j.fph.20120201.05

Järup, L. (2003). Hazards of heavy metal contamination. British

Medical Bulletin, 68, 167-182.

https://doi.org/10.1093/bmb/ldg032

Kashem, A., \& Singh, B. R. (1999). Heavy metal contamination of soil and vegetation in the vicinity of industries in Bangladesh. Water, Air, and Soil Pollution, 115(1-4), 347-361. https://doi.org/10.1023/A:1005193207319

Latapi, G., \& Barrett, D. M. (2006). Influence of Pre-drying Treatments on Quality and Safety of Sun-dried Tomatoes. Part I: Use of Steam Blanching, Boiling Brine Blanching, and Dips in Salt or Sodium Metabisulfite. In S24 JOURNAL OF FOOD SCIENCE (Vol. 71, Issue 1). www.ift.org

Oluwole, O. B., Awonorin, S. O., Henshaw, F., Elemo, G. N., \& Ebuehi, O. A. T. (2013). Assessment of Microbial Changes and Nutritional Qualities of Extruded White Yam (\&lt;i\&gt;Dioscorea rotundata\&lt;/i\&gt;) and Bambara Groundnut (\&lt;i\&gt;Vigna subterranean\&lt;/i\&gt;) Blends. Food and Nutrition Sciences, 04(01), 100-107. https://doi.org/10.4236/fns.2013.41014

Rafi, M., \& GowdaT, P. (2017). DETERMINATION OF HEAVY METAL ANALYSIS IN VEGETABLE SAMPLES OF BENGALURU AND TUMUKUR SOME MARKET PLACES, KARNATAKA, INDIA (Issue 4).

S, B., BG, M., \& B, B. (2017). Total Excess Lifetime Cancer Risk Estimation from Enhanced Heavy Metals Concentrations Resulting from Tailings in Katsina Steel Rolling Mill, Nigeria. Journal of Material Science \& Engineering, 06(03). https://doi.org/10.4172/2169-0022.1000338

Sultana, M. S., Rana, S., Yamazaki, S., Aono, T., Yoshida, S., \& Kanan, S. (2017). Health risk assessment for carcinogenic and non-carcinogenic heavy metal exposures from vegetables and fruits of Bangladesh. Cogent Environmental Science, 3(1), 1291107. https://doi.org/10.1080/23311843.2017.1291107

\section{https://doi.org/10.1080/23311843.2017.1291107}

Haiyan W, S. A. (2003). Heavy metal pollution in air-watersoil-plant. Water Air Soil Pollution, 147, 79-107.

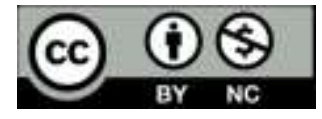

C2021 This is an Open Access article distributed under the terms of the Creative Commons Attribution 4.0 International license viewed via https://creativecommons.org/licenses/by/4.0/ which permits unrestricted use, distribution, and reproduction in any medium, provided the original work is cited appropriately. 